\title{
Työturvallisuus kotieläinrakennusten lattioiden pinnan laadun kriteerinä
}

\author{
Tiina Mattila $^{1)}$, Risto Rautiainen ${ }^{2)}$, Kim O. Kaustell ${ }^{1)}$ \& Juha Suutarinen ${ }^{1)}$ \\ ${ }^{1)}$ MTT maatalousteknologian tutkimus (Vakola), Vakolantie 55, 03400 Vihti \\ tiina.mattila@mtt.fi; kim.kaustell@mtt.fi, juha.suutarinen@mtt.fi \\ ${ }^{2)}$ The University of Iowa, College of Public Health, \\ Great Plains Center for Agricultural Health, \\ 100 Oakdale Campus, 103 IREH, Iowa City, Iowa 52242-5000, US \\ risto-rautiainen@uiowa.edu
}

\section{Tiivistelmä}

Tutkimuksen tavoitteena oli selvittää maatalouden kotieläinrakennusten lattiarakenteiden työturvallisuutta ja sen taloudellista merkitystä. Tämä tehtiin tarkastelemalla sellaisten liukastumis-, kompastumis- ja kaatumistapaturmien määrää ja seurauksia, joiden välittömäksi aiheuttajaksi oli tapaturmatiedoissa mainittu jokin tuotantorakennuksen lattiarakenne. Tutkimusaineistona oli Maatalousyrittäjien eläkelaitoksen (Melan) rekisteröimät nautakarjan tai sikojen hoitotöissä sattuneet edellä mainitut tapaturmat, joihin myönnettiin korvaus vuosina 1992-2002.

Määritelmän mukaisia kaatumis-, liukastumis-, tai kompastumistapaturmia, joiden välittömäksi aiheuttajaksi oli merkitty jokin lattiarakenne, kuten lattia, kynnys, ajoluiska, ruokintapöytä, lantakouru tai karsina sattui tarkastelujakson aikana 6414 kpl. Tämä oli noin 14 \% kaikista sikojen ja nautaeläinten hoitotöissä sattuneista tapaturmista. Keskimääräinen työkyvyttömyysaika oli 26 päivää. Yhteenlaskettu työkyvyttömyys oli 462 henkilötyövuotta. Vakavia eli yli kuukauden työkyvyttömyyden aiheuttaneita tapaturmia oli $22 \%$ ja ne aiheuttivat noin 60 \% työkyvyttömyyspäivistä.

Nautakarjan hoitotöissä lattioihin liittyvien kompastumisten, kaatumisten ja liukastumisten osuus kaikista työvaiheen tapaturmista oli korkea lantatöissä (25 \%) ja ruokinnassa (24 \%). Sikaloissa ko. tapaturmien osuus kaikista työvaiheen tapaturmista oli korkea lantatöissä (32 \%) ja rehun käsittelyssä (25\%).

Lattioihin liittyvät kompastumiset, liukastumiset ja kaatumiset aiheuttivat Melalle noin 11 milj $€$ kulut työkyvyttömyyskorvauksina tarkastelujakson aikana. Tämä oli 5,7 \% kaikista maksetuista korvauksista. Viljelijälle vahingosta aiheutuu vakuutusyhtiön korvaamien kustannusten lisäksi myös monia epäsuoria kustannuksia, joiden arvoa on vaikea määritellä. Tällaisia ovat esimerkiksi ajallisuuskustannukset, laatuvaikutukset, tuotannon menetykset, koneiden käyttöaikatappiot ja sivuansiomenetykset. Myöskään tapaturmista aiheutuvaa inhimillistä kärsimystä ei ole arvotettu.

Asiasanat: työturvallisuus, tapaturma, tuotantorakennukset, maatalous 


\section{Johdanto}

Kotieläinrakennukseen kohdistuu monia tekniseen toteutukseen, toiminnallisuuteen ja kestävyyteen liittyviä vaatimuksia (Kuva 1). Epäonnistuneet rakenneratkaisut heijastuvat muun muassa eläinten hyvinvoinnin heikkenemisenä, kuten iho- ja sorkkavaurioina, tuotantotoiminnan ja työn häiriöinä tai viivästyksinä sekä heikentyneenä työturvallisuutena. Onnistuneen rakennesuunnittelun edellytyksenä on ymmärrys lattian käyttöön liittyvistä olosuhteista ja vaatimuksista.

Kotieläintuotannossa sattuu vuosittain enemmän tapaturmia kuin missään muussa maataloustyövaiheessa Suomessa (Tike 2004). Esimerkiksi vuonna 2003 eläinten hoitotöissä sattui 2767 Maatalousyrittäjien eläkelaitoksen (Melan) rekisteröimää tapaturmaa eli noin 50 \% kaikista maataloustyössä sattuneista tapaturmista. Suurimmassa osassa tapauksista, tapaturman välitön aiheuttaja oli eläin (47 \%), mutta myös työympäristöllä on suuri merkitys. Työympäristö mainittiin tapaturman aiheuttajaksi noin 31 \%:ssa eläintenhoidossa sattuneista tapaturmista.

Tuotantorakennusten lattiarakenteisiin liittyvien työturvallisuusongelmien laajuutta ja taloudellista merkitystä arvioidaan tässä tutkimuksessa tarkastelemalla niiden aiheuttamien liukastumisten, kompastumisten ja kaatumisten määrää ja seurauksia.

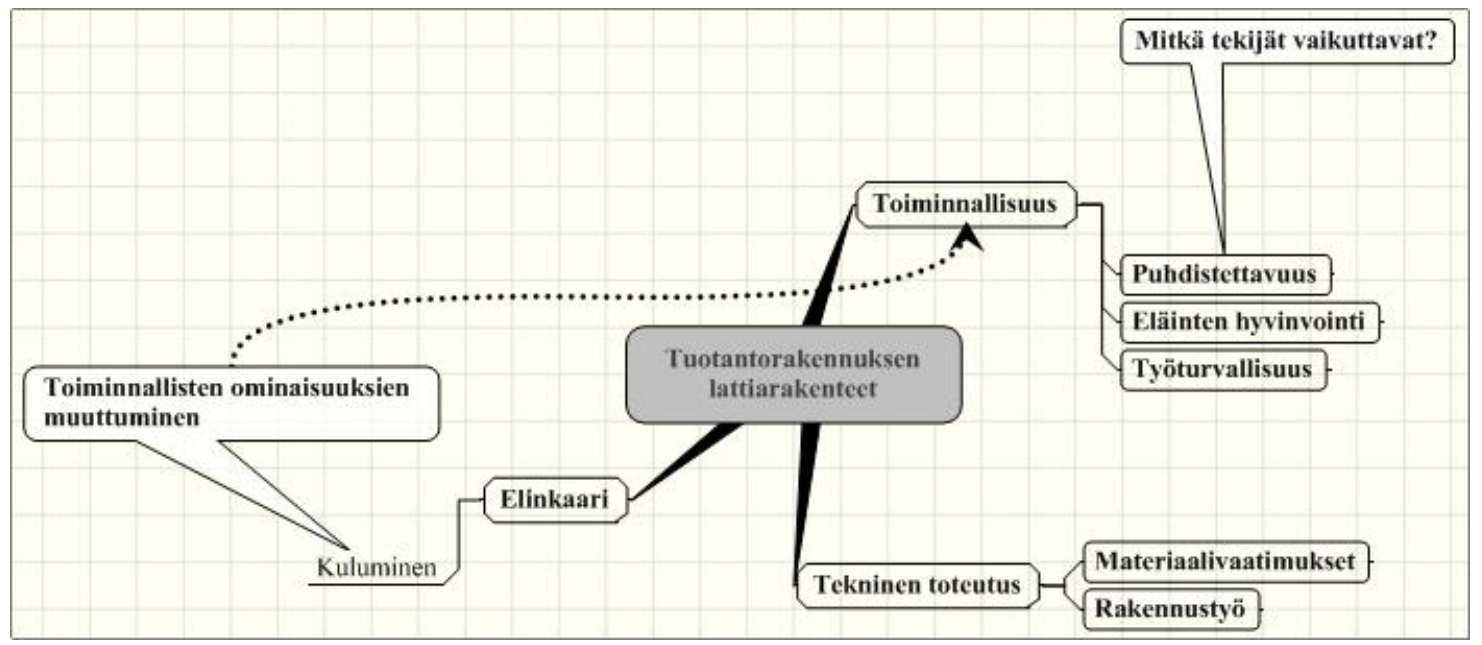

Kuva 1. Maatalouden tuotantorakennuksen lattiarakenteissa huomioon otettavia tekijöitä

\section{Aineisto ja menetelmät}

Tutkimusaineistona olivat Melan rekisteröimät nautakarjan tai sikojen hoitotöissä sattuneet liukastumis-, kompastumis- ja kaatumistapaturmat (LKK-tapaturmat), joihin myönnettiin korvaus vuosina 1992-2002. Analyysiin otettiin vain ne tapaturmat, joiden välitön aiheuttaja oli jokin lattiarakenne, kuten lattia, kynnys, ajoluiska, ruokintapöytä, lantakouru tai karsina. Melan tapaturmatilastossa 'välitön aiheuttaja' -muuttuja kuvaa sitä "fyysistä esinettä, työkalua tai tekijää, jonka kanssa vahingoittunut joutui tapaturmassa kosketuksiin”. Tehty rajaus jättää ulkopuolelle välittömistä aiheuttajista mm. useimmat koneet ja laitteet sekä kotieläimet. Vertailuaineistona käytettiin kaikkia Melan rekisteröimiä vuosina 1992-2002 korvattuja uusia, työaikana sattuneita tapaturmia sekä kaikkia sikojen ja nautaeläinten hoitotöissä sattuneita tapaturmia.

Tapaturma-aineiston perusteella selvitettiin tapaturmien määrä ja vakavien tapaturmien osuus. Lisäksi tarkasteltiin tapaturmien seurauksia työkyvyttömyyspäivinä ja arvioitiin sattuneiden tapaturmien taloudellista merkitystä.

\section{Tulokset ja tulosten tarkastelu}

Vuosina 1992 - 2002 sattui sikaloissa ja navetoissa 6414 LKK-tapaturmaa, jonka välitön aiheuttaja oli jokin lattiarakenne, kuten lattia, kynnys, ajoluiska, ruokintapöytä, lantakouru tai karsina. Tämä oli noin 14 \% sikojen ja nautaeläinten hoitotöissä sattuneista ja noin 6 \% kaikista Melan rekisteröimistä tapaturmista tarkastelujakson aikana. 
Keskimäärin kaatuminen, liukastuminen tai kompastuminen aiheutti 26 päivän työkyvyttömyyden. Yhteenlaskettu työkyvyttömyyspäivien lukumäärä tarkastelujakson aikana oli 168795 päivää (462 henkilötyövuotta, kun työvuodeksi lasketaan 365 pv). LKK-tapaturmista suurin osa (78 \%) oli lieviä tapaturmia. Vakavia eli yli kuukauden työkyvyttömyyden aiheuttaneita tapaturmia oli 22 \%. Työkyvyttömyyspäivistä kuitenkin noin 60 \% aiheutui vakavista tapaturmista.

Nautakarjan hoitotöissä lattioihin liittyviä LKK-tapaturmia sattui tarkastelujakson aikana määrällisesti eniten rehun siirron (962 kpl), ruokinnan (778 kpl), lypsyn (826 kpl) sekä lantatöiden (734 kpl) yhteydessä (Taulukko 1). LKK-tapaturmien osuus kaikista työvaiheen tapaturmista oli korkea lantatöissä (25 \%) ja ruokinnassa (24 \%). Lantatöillä tarkoitetaan tässä lannanpoistoa, käsittelyä ja kuivitusta. Ruokinta puolestaan tarkoittaa varsinaista ruokintapöydällä tapahtuvaa ruokintaa.

Tapaturmariskiä voidaan arvioida myös suhteuttamalla sattuneet tapaturmat työvaiheeseen kuluvaan työaikaan. Klemolan ym. (2000) tutkimuksen mukaan lypsytyön osuus karjanhoitotöihin käytetystä työajasta on 52-75 \%. Lypsyssä ja lypsyn valmistelussa sattuu kuitenkin vain noin $21 \%$ kaikista nautakarjan hoidossa sattuneista tapaturmista (Taulukko 1). Lattiarakenteiden aiheuttamien LKKtapaturmien osuus kaikista työvaiheen tapaturmista on selvästi suurempi lypsyn valmistelussa (19\%) kuin varsinaisessa lypsyssä (11 \%).

Sikaloissa tapaturmia sattuu eniten lantatöissä ja eläinten siirtojen yhteydessä (Taulukko 1). Lattiarakenteisiin liittyviä LKK-tapaturmia sattui määrällisesti eniten lantatöissä (390 kpl) ja rehun käsittelyssä (245 kpl). LKK-tapaturmien osuus näissä työvaiheissa sattuneista kaikista tapaturmista oli korkea, lantatöissä $32 \%$ ja rehun käsittelyssä $25 \%$.

Taulukko 1. Nautakarjan ja sikojen hoitotöissä sattuneet tapaturmat $1992-2002$

\begin{tabular}{|c|c|c|}
\hline Työvaihe & $\begin{array}{l}\text { Tapaturmien määrä } \\
(1992-2002)\end{array}$ & $\begin{array}{l}\text { LKK-tapaturmien } \\
\text { määrä ja (osuus \%) }\end{array}$ \\
\hline \multicolumn{3}{|l|}{ Nautakarjan hoitotyöt } \\
\hline Ruoan valmistus & 598 & $45(8)$ \\
\hline Rehun siirto & 6954 & $962(14)$ \\
\hline Ruokinta & 3236 & $778(24)$ \\
\hline Juotto & 1210 & $252(21)$ \\
\hline Lantatyöt & 2894 & $734(25)$ \\
\hline Navetan siivous & 1243 & $265(21)$ \\
\hline Eläinten harjaus ja puhdistus & 389 & $27(7)$ \\
\hline Veden lämmittäminen & 531 & $42(8)$ \\
\hline Lypsyn valmistelu & 1653 & 309 (19) \\
\hline Lypsy & 7233 & $826(11)$ \\
\hline Eläinten kuljetus ja siirto & 8578 & $525(6)$ \\
\hline Siemennys, poi'itus yms. & 2800 & $328(12)$ \\
\hline Työmatkat & 2478 & $161(6)$ \\
\hline Muut & 1893 & $255(13)$ \\
\hline \multicolumn{3}{|l|}{ Sikojen hoitotyöt } \\
\hline Sikojen hoitotyöt & 275 & 0 \\
\hline Rehun käsittely & 996 & $245(25)$ \\
\hline Lantatyöt, puhdistus & 1208 & $390(32)$ \\
\hline Eläinten siirto & 1134 & $140(12)$ \\
\hline Siemennys, porsitus yms. & 535 & $48(9)$ \\
\hline Työmatkat & 407 & $22(5)$ \\
\hline Muut & 389 & $60(15)$ \\
\hline Yhteensä & 46634 & $6414(14)$ \\
\hline
\end{tabular}


Kaila-Kangas ym. (2000) ja Suutarisen (2003) mukaan tapaturmia sattuu todellisuudessa enemmän kuin mitä vakuutustiedoista käy selville. Mainittujen tutkimusten mukaan noin yksi kolmasosa tapaturmista ei johda työstä poissaoloon. Vaikka työstä poissaolo ei olekaan ainoa korvauksen saamisen edellytys, voidaan olettaa, että kaikkia tapaturmia ei ilmoiteta vakuutusyhtiölle. Tutkimuksessa (KailaKangas ym. 2000) saatiin myös viitteitä siitä, että vammatyypeistä erityisesti venähdykset ja nyrjähdykset jäävät usein ilmoittamatta. Tämän perusteella voidaan epäillä, että LKK-tapaturmia sattuu käytännössä jopa noin 30 \% enemmän kuin mitä Melan rekisteristä selviää.

\section{Taloudellinen merkitys}

Rautiainen (2002) arvioi, että vuonna 1996 maataloustapaturmissa aiheutuneiden vammojen välittömät kustannukset ilman materiaalitappioita olivat keskimäärin $1340 €$ tapaturmaa kohti. Vuonna 1996 sattui 635 LKK-tapaturmaa, joissa välitön aiheuttaja oli jokin lattiarakenne. Kun käytetään Rautiaisen (2002) laskemaa keskimääräistä $1340 €$ kustannusta, niin saadaan vuonna 1996 lattiarakenteista aiheutuneiden LKK-tapaturmien välittömiksi kustannuksiksi $850900 €$. Rautiaisen (2002) tutkimuksen mukaan tapaturmien ja ammattitautien kokonaiskustannukset olivat 23,5 milj. € vuonna 1996. Lattiarakenteisiin liittyvien LKK-tapaturmien osuus oli siis 3,6 \% kaikista kustannuksista vuonna 1996.

LKK-tapaturmien kustannuksia eri vuosina voidaan arvioida myös Melan (2003) tilastojen perusteella. Tilastojen perusteella Mela maksoi vuosina 1992-2002 korvauksia työaikana sattuneista tapaturmista yhteensä noin 198 milj €. Keskimääräinen tapaturmakustannus on tarkastelujakson aikana kasvanut noin 1347 eurosta 2936 euroon. LKK-tapaturmien kustannuksia voidaan karkeasti arvioida keskimääräisen tapaturmakustannuksen perusteella. Lattiarakenteisiin liittyvien LKK-tapaturmien osuus maksetuista korvauksista oli tämän perusteella 11324730 euroa (5,7 \%) vuosina 1992-2002 (Mela 2003).

Viljelijälle vahingosta aiheutuu vakuutusyhtiön korvaamien kustannusten lisäksi yleensä erilaisia epäsuoria kustannuksia, joiden arvoa on vaikea määritellä. Tällaisia ovat esimerkiksi ajallisuuskustannukset eli ajallisesti tiettyyn aikaan tehtävien töiden viivästymisestä aiheutuneet kustannukset, laatuvaikutukset, tuotannon menetykset, koneiden käyttöaikatappiot ja sivuansiomenetykset. (Suutarinen ym. 2002). Lisäksi tapaturma ja sitä mahdollisesti seuraava sairasloma voivat aiheuttaa ylimääräistä henkistä kuormittumista ja perheyrityksessä töiden kasaantumista puolisolle tai muille tilalla työskenteleville.

\section{Johtopäätökset}

Vaikka käytetty tilastoaineisto ei todennäköisesti tuonut esiin läheskään kaikkia sattuneita liukastumis, kaatumis- ja kompastumistapaturmia, niin tämänkin aineiston perusteella on selvää, että työturvallisuuteen on kotieläinrakennuksissa syytä kiinnittää nykyistä enemmän huomiota. Onnistuneella kotieläintilojen lattiarakenteiden suunnittelulla, rakentamisella ja ylläpidolla voidaan tulosten perusteella arvioida olevan mahdollisuus merkittävästi vähentää tapaturmia ja niiden seuraamuksia.

Tapaturmien ehkäisyssä kannattaa keskittyä erityisesti vakavien tapaturmien ehkäisyyn. Ne aiheuttavat huomattavan suuren osan työkyvyttömyyspäivistä ja siis myös taloudellisista menetyksistä. Tulokset ovat samansuuntaisia kuin Rautiaisen ym. (2005) tutkimuksessa, jossa todetaan että $20 \%$ 80 \% sääntö pätee maataloudessa siten että 20 \% tapaturmista aiheuttaa 80 \% kustannuksista.

Tämän tilastotarkastelun perusteella ei voida tarkasti määritellä sitä, mitkä tekijät lattiarakenteissa tai niiden ylläpidossa ovat erityisesti yhteydessä kaatumisiin, liukastumisiin ja kompastumisiin. Kaatumis-, liukastumis- ja kompastumistapaturmien riski näyttää olevan korkea erityisesti lannanpoistoon sekä toisaalta ruokintaan liittyvissä töissä. Tapaturmien tyypilliset aiheuttajat voivat eri työvaiheissa olla kuitenkin hyvin erilaisia. Syy-yhteyksiä ja olosuhteita on jatkossa tarkoitus tutkia analysoimalla vakavien tapaturmien case-kuvauksia, jotta voidaan entistä selkeämmin ohjeistaa työsuojelun huomioon ottaminen tuotantorakennusten lattioiden suunnittelussa ja toteutuksessa. Lisäksi tapaturmatrendejä tarkastelemalla voidaan arvioida esimerkiksi teknologiamuutosten ja tilakoon muuttumisen yhteyksiä tapaturmien määrän ja laadun muutoksiin. Näin voidaan osaltaan kehittää kotieläintilojen riskienhallintaa ja alentaa tuotantokustannuksia. 


\section{Kirjallisuus}

Kaila-Kangas, L., Virtanen, S. \& Vänskä, J. 2000. maatalousyrittäjien työtapaturmat ja koetut työperäiset sairaudet. Teoksessa: Paananen, S. (toim.) Työn vaarat 1999. Koetut työperäiset sairaudet, työtapaturmat ja työväkivaltatapaukset. Työmarkkinat 15. Helsinki: Tilastokeskus. s. 79-90.

Klemola, E., Pihamaa, P. \& Heikkilä, A-M. 2000. Laajentavan lypsykarjatilan tuotannon ja työnkäytön suunnittelu. Työtehoseuran julkaisuja 375. Helsinki: TTS. 88 s.

Mela 2003. Maatalousyrittäjien eläkelaitos, Internet sivut: http://www.mela.fi/main.asp?path=694. Viitattu 16.9.2003.

Rautiainen, R. 2002. Injuries and occupational diseases in agriculture in Finland; cost, length of disability, and preventive effect of a no-claims bonus. University of Iowa. $200 \mathrm{~s}$.

Rautiainen, R.H., Ohsfeldt, R., Sprince, N.L., Donham, K.J., Bureister, L.F., Reynolds, S.J., Saarimäki, P. \& Zwerling, C. 2005. Cost of Compensaetd Injuries and Occupational Diseases in Agriculture in Finland. Journal of Agromedicine 10(3): 21 - 29.

Suutarinen, J. 2003. Occupational Accidents in Finnish Agriculture - Causality and Management Aspects for Prevention. Agrofood Research Reports 39: 75 s. +liitteet. http://www.mttt.fi/met/pdf/met39.pdf Verkkojulkaisu, päivitetty 28.11.2003.

Suutarinen, J., Lehto, M., Karttunen, J., Salonen, K., Nysand, M., Mäkelä, K. \& Manni, J. 2002. Työsuojelupanostuksen kannattavuus maataloudessa. Maa- ja elintarviketalous 6. Vihti: MTT maatalousteknologian tutkimus. 80 s. Saatavissa internetistä: http://www.mtt.fi/met

Tike 2004. Maatilatilastollinen vuosikirja 2004. MMM tietopalvelukeskus. 268 s. 